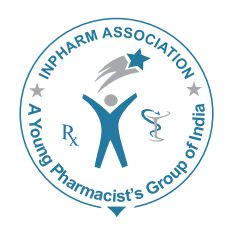

\title{
JVP
}

\section{Formulation and Evaluation of Cephalexin Extended Release Matrix Tablets Using $3^{2}$ Factorial Design}

\author{
Jishnu V, Prabhakaran R ${ }^{1}$, Gilhotra RM \\ Department of Pharmaceutics, School of Pharmacy, Suresh Gyan Vihar University, Jaipur, \\ ${ }^{1}$ Sance Laboratories Pvt. Ltd., Kottayam, Kerala, India \\ Address for correspondence: Dr. Ritu M Gilhotra; E-mail: ritugilhotra@yahoo.co.in
}

\begin{abstract}
The aim of the present investigation was to prepare extended release film coated matrix tablets of cephalexin using binary mixture of two grades of hydrophilic polymer, hydroxypropyl methyl cellulose (HPMC), by direct compression method. Results of the preliminary trials indicated that the polymers used have significant release retarding effect on the formulation. To study the effect of concentration of polymers on drug release from matrix tablets, $3^{2}$ full factorial design was applied. The concentration of HPMC K15M and HPMC $15 \mathrm{cps}$ were used as independent variables, while percentage drug release was selected as dependent variable. The dissolution data were fitted into zero-order, first-order, Higuchi and Korsemeyer-Peppas models to identify the pharmacokinetics and mechanism of drug release. Comparative study of dissolution profile of final batch F3 with market preparation (Sporidex AF 375 ) was done by similarity factor $\left(\mathrm{f}_{2}\right)$ determination and it was concluded that final formulation F3 (10\% HPMC K15M, 17.5\% HPMC 15cps) shows good similarity with the market product. The results of the accelerated stability study of final formulation F3 for 1 month revealed that storage conditions were not found to have made any significant changes in final formulation F3. The release of cephalexin was prolonged for $6 \mathrm{~h}$ by using polymer combinations of HPMC and a twice daily matrix tablet was formulated.
\end{abstract}

Key words: Cephalexin, factorial design, hydroxypropyl methyl cellulose, matrix tablets, release kinetics, similarity factor $\left(\mathrm{f}_{2}\right)$

\section{INTRODUCTION}

Oral delivery of drugs is by far the most preferable route of drug delivery due to the ease of administration, patient

\begin{tabular}{|l|l|}
\hline \multicolumn{2}{|c|}{ Access this article online } \\
\hline Quick Response Code: & \\
\hline & Website: \\
\hline
\end{tabular}

compliance and flexibility in formulation. Extended release oral drug formulations have been used since 1960s to enhance performance and increase patient compliance. ${ }^{[1]}$ By incorporating the dose for $24 \mathrm{~h}$ into one tablet from which the drug is slowly released, peaks of high plasma concentration and troughs of low plasma concentration can be prevented. ${ }^{[2]}$ This helps to avoid the side effects associated with high concentrations and the lack of activity associated with low concentrations, giving better overall therapy. In biopharmaceutics, scientists generally are faced with an engineering problem: To develop drug delivery systems that hit a desired target. The target in pharmacokinetics 
is generally a plasma/blood drug concentration that lies between the minimum effect concentration (MEC) and minimum toxic concentration (MTC). Cephalexin is a semisynthetic antibiotic derived from cephalosporin $\mathrm{C}$ and is almost completely absorbed from the gastrointestinal tract, with a bioavailability of $95 \%$. Cephalexin has a half-life of around $1.1 \mathrm{~h}^{\left[{ }^{[3-5]}\right.}$ To maintain therapeutic range, the drug should be administered 3-4 times a day, which leads to sawtooth kinetics and resulting in ineffective therapy. ${ }^{[6]}$ Addressing this problem, we attempted to formulate extended release tablets of cephalexin, which can provide constant effective drug level for $6 \mathrm{~h}$, based on calculations considering pharmacokinetic parameters.

\section{MATERIALS AND METHODS}

\section{Materials}

The chemicals used in the experiment were: Cephalexin monohydrate (Aurobindo Pharma Ltd., Hyderabad, India), microcrystalline cellulose PH102 (Weiming Industries, China), lactose anhydrous (DMV-Fonterra Excipients, Germany), hydroxypropyl methyl cellulose (HPMC) 15cps and HPMC K15M (Feicheng Ruitai Fine chemicals, China), colloidal silicon dioxide (Degussa India Pvt. Ltd., Mumbai, India), magnesium stearate (Ferro Corporation, USA), Sporidex AF 375 (Ranbaxy laboratories Pvt. Ltd., Gurgaon, India). All the other reagents used were of analytical grade.

\section{Methods}

Preparation and evaluation of cephalexin monohydrate granules ${ }^{[7]}$ Accurately weighed quantities of drug and excipients were passed through sieve no: 20 and 40, respectively. Drug and excipients (excluding lubricant) were added in geometric proportions and mixed thoroughly for $15 \mathrm{~min}$. The blend was mixed finally with lubricant to get the granules of cephalexin monohydrate. The flow properties of granules were characterized in terms of angle of repose, Carr's index and Hausner's ratio. The bulk density and tapped density were determined using USP bulk density apparatus (Veego Industries, Mumbai, India). The data summarized in Table 1.

Formulation of cephalexin matrix tablets using direct compression method $^{87}$

The prepared granules of cephalexin monohydrate were compressed in $15 \times 8.5 \mathrm{~mm}$ punches of 27 station rotary tablet compression machine (CMB4D Cadmach, Ahmadabad, India). The formulae for batches F1-F9 are shown in Tables 2 and 3.
Table 1: Pre-compression parameters of final batches F1-F9

\begin{tabular}{lccccc}
\hline Code & $\begin{array}{c}\text { Angle of } \\
\text { repose }(\theta)^{*}\end{array}$ & $\begin{array}{c}\text { Bulk } \\
\text { density } \\
\left(\mathrm{g} / \mathbf{c m}^{3}\right)\end{array}$ & $\begin{array}{c}\text { Tapped } \\
\text { density } \\
\left(\mathrm{g} / \mathbf{c m}^{3}\right)\end{array}$ & $\begin{array}{c}\text { Carr's } \\
\text { index }(\%)\end{array}$ & $\begin{array}{c}\text { Hausner's } \\
\text { ratio }\end{array}$ \\
\hline F1 & $32^{\circ} 21^{\prime} \pm 0.57$ & $0.58 \pm 0.41$ & $0.72 \pm 0.18$ & $19.22 \pm 0.31$ & $1.23 \pm 0.43$ \\
F2 & $34^{\circ} 16^{\prime} \pm 0.32$ & $0.57 \pm 0.54$ & $0.68 \pm 0.23$ & $16.22 \pm 0.58$ & $1.19 \pm 0.38$ \\
F3 & $33^{\circ} 35^{\prime} \pm 0.64$ & $0.56 \pm 0.27$ & $0.67 \pm 0.45$ & $16.14 \pm 0.19$ & $1.19 \pm 0.87$ \\
F4 & $34^{\circ} 45^{\prime} \pm 0.87$ & $0.57 \pm 0.36$ & $0.70 \pm 0.52$ & $17.75 \pm 0.72$ & $1.21 \pm 0.66$ \\
F5 & $32^{\circ} 31^{\prime} \pm 0.49$ & $0.58 \pm 0.19$ & $0.72 \pm 0.31$ & $19.97 \pm 0.54$ & $1.24 \pm 0.33$ \\
F6 & $34^{\circ} 43^{\prime} \pm 0.71$ & $0.54 \pm 0.32$ & $0.65 \pm 0.49$ & $16.67 \pm 0.27$ & $1.20 \pm 0.18$ \\
F7 & $35^{\circ} 17^{\prime} \pm 0.36$ & $0.56 \pm 0.67$ & $0.68 \pm 0.48$ & $18.10 \pm 0.16$ & $1.22 \pm 0.25$ \\
F8 & $35^{\circ} 26^{\prime} \pm 0.25$ & $0.56 \pm 0.22$ & $0.68 \pm 0.14$ & $16.88 \pm 0.23$ & $1.20 \pm 0.55$ \\
F9 & $34^{\circ} 43^{\prime} \pm 0.68$ & $0.55 \pm 0.12$ & $0.66 \pm 0.65$ & $16.19 \pm 0.69$ & $1.19 \pm 0.79$ \\
\hline *The values are expressed as Mean $\pm \mathrm{SD} ; n=3$ & &
\end{tabular}

Table 2: Composition of optimization batches F1-F5

\begin{tabular}{lccccc}
\hline Ingredients & \multicolumn{5}{c}{ Quantity used (mg/tab) } \\
\cline { 2 - 6 } & F1 & F2 & F3 & F4 & F5 \\
\hline Cephalexin monohydrate & 401.25 & 401.25 & 401.25 & 401.25 & 401.25 \\
Microcrystalline cellulose & 22.15 & 36.65 & 7.65 & 33.75 & 48.25 \\
HPMC K15M & 58.00 & 58.00 & 58.00 & 46.40 & 46.40 \\
HPMC K15cps & 87.00 & 72.50 & 101.50 & 87.00 & 72.50 \\
Colloidal silicon dioxide & 5.80 & 5.80 & 5.80 & 5.80 & 5.80 \\
Magnesium stearate & 5.80 & 5.80 & 5.80 & 5.80 & 5.80 \\
Average tablet weight & 580.00 & 580.00 & 580.00 & 580.00 & 580.00 \\
\hline
\end{tabular}

Table 3: Composition of optimization batches F6-F9

\begin{tabular}{lcccc}
\hline Ingredients & \multicolumn{4}{c}{ Quantity used (mg/tab) } \\
\cline { 2 - 5 } & F6 & F7 & F8 & F9 \\
\hline Cephalexin monohydrate & 401.25 & 401.25 & 401.25 & 401.25 \\
Microcrystalline cellulose & 19.25 & 45.35 & 59.85 & 30.85 \\
HPMC K15M & 46.40 & 34.80 & 34.80 & 34.80 \\
HPMC K15cps & 101.50 & 87.00 & 72.50 & 101.50 \\
Colloidal silicon dioxide & 5.80 & 5.80 & 5.80 & 5.80 \\
Magnesium stearate & 5.80 & 5.80 & 5.80 & 5.80 \\
Average tablet weight & 580.00 & 580.00 & 580.00 & 580.00 \\
\hline
\end{tabular}

\section{Evaluation of tablet properties ${ }^{8,9}$}

The prepared cephalexin matrix tablets were evaluated for thickness, hardness, friability, uniformity of weight and drug content. The thicknesses of tablets were measured using vernier caliper (Aerospace, China). Hardness of tablets was tested using a validated modified dial type hardness tester (Shivani Scientific Industries, Mumbai, India). Friability of tablets was determined by using Roche Friabilator (Electrolabs, Banglore, India). The drug content of each batch was determined as per USP assay of cephalexin using high performance liquid chromatography (HPLC; SCL-10AVP, Shimadzu Corporation, Japan). ${ }^{[10]}$ The results are shown in Table 4.

In vitro drug release study

The drug release studies of cephalexin matrix tablets were performed using dissolution testing apparatus USP type I (Basket type; Electrolabs, Banglore, India). The dissolution 
testing was performed using $900 \mathrm{ml}$ of $0.01 \mathrm{~N} \mathrm{HCl}$ for the $1^{\text {st }} \mathrm{h}$ and phosphate buffer, $\mathrm{pH} 6.8$, from $2^{\text {nd }} \mathrm{h}$ to $6^{\text {th }} \mathrm{h}$ at $37 \pm 0.5^{\circ} \mathrm{C}$ temperature and speed $100 \mathrm{rpm}$ for $6 \mathrm{~h}$. A sample $(5 \mathrm{ml})$ of the solution was withdrawn from the dissolution testing apparatus at $1^{\text {st }}, 2^{\text {nd }}, 4^{\text {th }}$ and $6^{\text {th }} \mathrm{h}$ and the samples were replaced with fresh dissolution medium. The samples were filtered through a $0.45 \mu \mathrm{m}$ membrane filter and diluted to a suitable concentration with the corresponding medium. Absorbance of these solutions was measured at $262 \mathrm{~nm}$ using UV-1650 spectrophotometer (Shimadzu Corporation, Japan). ${ }^{[1]]}$ The in vitro drug release specification was $20-40 \%$ at $1^{\mathrm{st}} \mathrm{h}, 40-60 \%$ at $2^{\text {nd }} \mathrm{h}, 60-80 \%$ at $4^{\text {th }} \mathrm{h}$ and $>80 \%$ at $6^{\text {th }} \mathrm{h}$, determined from theoretical drug release and dissolution pattern of the marketed product. The in vitro drug release data is a singular term which shows a single set of grouped data shown in Table 5 and also graphically represented in Figures 1 and 2.

\section{Experimental design ${ }^{[12,13]}$}

A $3^{2}$ full factorial design was adopted and the amount of polymers, HPMC K15M ( $\left.\mathrm{X}_{1}\right)$ and HPMC K15cps $\left(\mathrm{X}_{2}\right)$, were taken as independent variables and cumulative percentage drug release at $1^{\text {st }} \mathrm{h}\left(\mathrm{Y}_{1}\right), 2^{\text {nd }} \mathrm{h}\left(\mathrm{Y}_{2}\right)$ and $4^{\text {th }} \mathrm{h}\left(\mathrm{Y}_{3}\right)$ was taken as dependent variables as shown in Table 6 . The factors were studied at three levels $(-1,0,+1)$ indicating

Table 4: Post-compression parameters of optimization batches F1-F9

\begin{tabular}{lccccc}
\hline Formulation & $\begin{array}{c}\text { Weight } \\
\text { variation } \\
(\%) *\end{array}$ & $\begin{array}{c}\text { Thickness } \\
(\mathrm{mm})^{*}\end{array}$ & $\begin{array}{c}\text { Hardness } \\
\left(\mathrm{kg} / \mathrm{cm}^{2}\right)^{*}\end{array}$ & $\begin{array}{c}\text { Drug } \\
\text { content } \\
(\%)\end{array}$ & $\begin{array}{c}\text { Friability } \\
(\%)^{* *}\end{array}$ \\
\hline F1 & $1.32 \pm 1.34$ & $5.46 \pm 0.05$ & $10.26 \pm 1.11$ & 97.19 & $0.03 \pm 0.35$ \\
F2 & $2.37 \pm 2.16$ & $5.54 \pm 0.06$ & $12.59 \pm 2.20$ & 95.66 & $0.04 \pm 0.51$ \\
F3 & $2.13 \pm 1.48$ & $5.52 \pm 0.04$ & $11.23 \pm 1.25$ & 96.12 & $0.03 \pm 0.82$ \\
F4 & $2.74 \pm 2.79$ & $5.43 \pm 0.08$ & $11.46 \pm 1.74$ & 96.64 & $0.04 \pm 0.53$ \\
F5 & $1.55 \pm 3.13$ & $5.57 \pm 0.07$ & $10.28 \pm 2.28$ & 97.23 & $0.02 \pm 0.67$ \\
F6 & $2.31 \pm 2.42$ & $5.43 \pm 0.05$ & $12.22 \pm 2.35$ & 95.16 & $0.06 \pm 0.18$ \\
F7 & $1.12 \pm 3.19$ & $5.56 \pm 0.06$ & $10.61 \pm 1.76$ & 94.89 & $0.03 \pm 0.52$ \\
F8 & $2.07 \pm 3.67$ & $5.54 \pm 0.04$ & $11.55 \pm 2.22$ & 98.48 & $0.05 \pm 0.76$ \\
F9 & $2.72 \pm 2.43$ & $5.45 \pm 0.02$ & $10.57 \pm 2.36$ & 96.53 & $0.02 \pm 0.84$ \\
\hline
\end{tabular}

*Values are expressed as mean $\pm \mathrm{SD} ; n=20 . * *$ Values are expressed as mean $\pm \mathrm{SD} ; n=3$

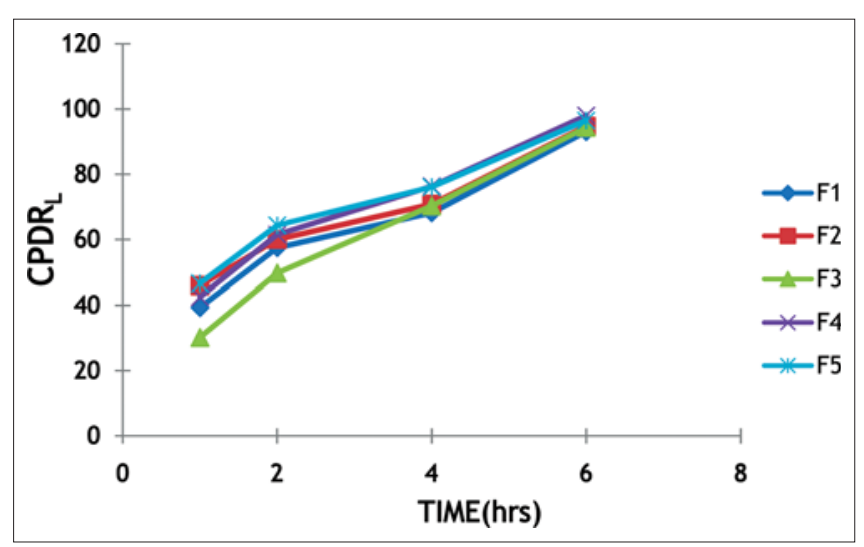

Figure 1: Cumulative percentage drug release of F1-F5 low, medium and high, respectively, as represented in Table 7. The statistical optimization procedure was performed with the help of optimization softwares like Design Expert 8 (Stat-Ease Inc., Minneapolis, MN, USA)

Table 5: Dissolution profiles of optimization batches F1-F9

\begin{tabular}{lcccc}
\hline $\begin{array}{l}\text { Formulation } \\
\text { code }\end{array}$ & \multicolumn{4}{c}{ Cumulative percentage drug release (\%)* } \\
\cline { 2 - 5 } & $\mathbf{1}^{\text {st }} \mathbf{h}$ & $\mathbf{2}^{\text {nd }} \mathbf{h}$ & $\mathbf{4}^{\text {th }} \mathbf{h}$ & $\mathbf{6}^{\text {th }} \mathbf{h}$ \\
\hline F1 & $39.31 \pm 0.73$ & $57.48 \pm 0.99$ & $68.16 \pm 0.99$ & $93.07 \pm 1.10$ \\
F2 & $45.96 \pm 0.72$ & $59.99 \pm 1.02$ & $70.82 \pm 0.99$ & $94.74 \pm 1.29$ \\
F3 & $30.18 \pm 1.12$ & $49.74 \pm 1.54$ & $70.24 \pm 1.50$ & $94.38 \pm 0.76$ \\
F4 & $42.51 \pm 0.73$ & $61.47 \pm 1.30$ & $76.33 \pm 0.73$ & $98.00 \pm 1.24$ \\
F5 & $46.64 \pm 0.62$ & $64.36 \pm 0.89$ & $76.09 \pm 0.80$ & $96.48 \pm 1.08$ \\
F6 & $33.64 \pm 0.89$ & $55.22 \pm 0.74$ & $73.21 \pm 0.90$ & $97.34 \pm 0.80$ \\
F7 & $43.96 \pm 1.02$ & $64.34 \pm 1.69$ & $82.41 \pm 1.01$ & $97.12 \pm 0.92$ \\
F8 & $48.68 \pm 0.65$ & $68.49 \pm 0.78$ & $84.39 \pm 1.15$ & $98.45 \pm 0.59$ \\
F9 & $35.13 \pm 1.35$ & $58.76 \pm 0.81$ & $81.85 \pm 0.93$ & $98.34 \pm 0.89$ \\
\hline *Values are expressed as mean $\pm S D ; n=6$ & &
\end{tabular}

Table 6: Factors and responses evaluated in $3^{2}$ factorial design

\begin{tabular}{|c|c|c|c|c|c|}
\hline \multirow[t]{2}{*}{$\begin{array}{l}\text { Formulation } \\
\text { code }\end{array}$} & \multicolumn{2}{|c|}{$\begin{array}{l}\text { Factors in coded } \\
\text { form }\end{array}$} & \multicolumn{3}{|c|}{ Responses (\%) } \\
\hline & $\begin{array}{c}\text { HPMC } \\
\text { K15M } \\
\left(X_{1}\right) \\
\end{array}$ & $\begin{array}{c}\text { HPMC } \\
15 \mathrm{cps} \\
\left(\mathrm{X}_{2}\right) \\
\end{array}$ & $\begin{array}{c}\text { Drug } \\
\text { release at } \\
1^{\text {st }} h\left(Y_{1}\right)\end{array}$ & $\begin{array}{c}\text { Drug } \\
\text { release at } \\
2^{\text {nd }} h\left(Y_{2}\right) \\
\end{array}$ & $\begin{array}{c}\text { Drug } \\
\text { release at } \\
4^{\text {th }} \mathrm{h}\left(\mathrm{Y}_{3}\right)\end{array}$ \\
\hline F1 & 0.0 & 0.0 & 42.51 & 61.47 & 76.33 \\
\hline $\mathrm{F} 2$ & 0.0 & 1.0 & 33.64 & 55.22 & 73.21 \\
\hline F3 & 1.0 & 1.0 & 30.18 & 49.74 & 70.24 \\
\hline $\mathrm{F} 4$ & 1.0 & 0.0 & 39.31 & 57.48 & 68.16 \\
\hline F5 & -1.0 & 1.0 & 35.13 & 58.76 & 81.85 \\
\hline F6 & 1.0 & -1.0 & 45.96 & 59.99 & 70.82 \\
\hline F7 & -1.0 & 0.0 & 43.96 & 64.34 & 82.41 \\
\hline F8 & 0.0 & -1.0 & 46.64 & 64.36 & 76.09 \\
\hline F9 & -1.0 & -1.0 & 48.68 & 68.49 & 84.39 \\
\hline
\end{tabular}

Table 7: Correlation of actual and coded factors

\begin{tabular}{lcccccc}
\hline Factor level & $\begin{array}{c}\text { Coded } \\
\text { form }\end{array}$ & \multicolumn{2}{c}{ Actual value $(\mathbf{m g})$} & & \multicolumn{2}{c}{ Actual value (\%) } \\
\cline { 3 - 4 } \cline { 7 - 8 } & & HPMC & HPMC & & HPMC & HPMC \\
& & K15M & K15M & & K15M & $\mathbf{1 5 c p s}$ \\
\hline Low & -1 & 34.80 & 72.50 & & 6.00 & 12.50 \\
Medium & 0 & 46.40 & 87.00 & & 8.00 & 15.00 \\
High & +1 & 58.00 & 101.50 & & 10.00 & 17.50 \\
\hline
\end{tabular}

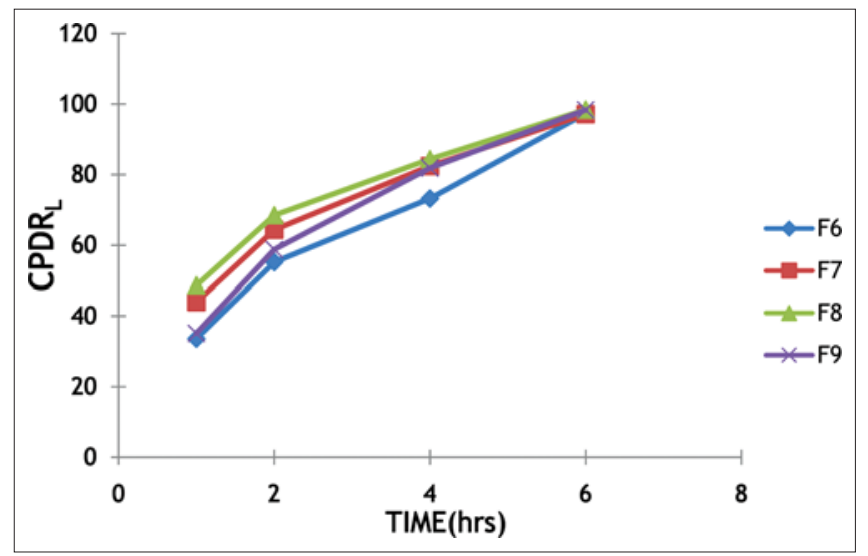

Figure 2: Cumulative percentage drug release of F6-F9 
and Statgraphics Centurion XVI (StatPoint Technologies, Inc. Warrenton, Virginia, USA). The software performs the multiple regression analysis (MRA), analysis of variance (ANOVA) and statistical optimization.

\section{Multiple regression analysis ${ }^{[12]}$}

The use of regression analysis in $3^{2}$ factorial design generates polynomial equations for different models, with interacting terms and regression coefficients, useful in evaluating the responses. The software generates two models, particularly, full model (non-significant terms included) and reduced model (excluding non-significant terms). In the full model study, the responses were analyzed using the quadratic equation below:

$$
\mathrm{Y}=\mathrm{b}_{0}+\mathrm{b}_{1} \mathrm{X}_{1}+\mathrm{b}_{2} \mathrm{X}_{2}+\mathrm{b}_{12} \mathrm{X}_{1} \mathrm{X}_{2}+\mathrm{b}_{11} \mathrm{X}_{1}^{2}+\mathrm{b}_{22} \mathrm{X}_{2}^{2}
$$

where $\mathrm{Y}$ is the response evaluated, $\mathrm{b}_{0}$ is the arithmetic mean response of 9 runs and $b_{i}$ is the estimated coefficient of $\mathrm{X}_{\mathrm{i}}$. The main effects $\left(\mathrm{X}_{1}\right.$ and $\left.\mathrm{X}_{2}\right)$ represent the average result of changing one factor at a time from its low to high value. The interaction term $\left(\mathrm{X}_{1} \mathrm{X}_{2}\right)$ shows how the response changes when two factors are simultaneously changed. The polynomial terms $\left(\mathrm{X}_{1}^{2}\right.$ and $\left.\mathrm{X}_{2}^{2}\right)$ were included to investigate nonlinearity.

In the reduced model study, the non-significant terms in the quadratic equation are removed using backward regression procedure to generate a reduced model which is more important in studying the influence of factors on the responses evaluated. The value and sign of regression coefficient $\left(\mathrm{b}_{\mathrm{i}}\right)$ indicates the magnitude of influence of the particular term on the response. The regression coefficients give the average change in a response when the particular factor is changed by a unit, when all the other terms remain constant. A positive sign on the regression coefficient indicates the factor has a positive effect on the response and negative sign indicates a negative effect.

\section{ANOVA study ${ }^{[13]}$}

The software performs the individual analysis of responses and calculates the sum of squares (SS), mean square (MS), Fischer's ratio (F statistics) and $P$ value. The F statistics and $P$ value give the significance level of each term, considering the null hypothesis $\left(\mathrm{H}_{0}\right)$ is true. The terms with a $P$ value less than 0.05 are considered significant at a level of significance $\alpha=0.05$. When the $F$ value obtained is greater than the critical $\mathrm{F}$ value from the $\mathrm{F}$ distribution table, the factor becomes significant and the null hypothesis is rejected.

\section{Comparison of dissolution profiles ${ }^{[14]}$}

The similarity in drug release pattern of the marketed product (Sporidex AF 375) and the formulation developed was compared by similarity factor $\left(\mathrm{f}_{2}\right)$ determination. The two products are said to be similar if the value of $f_{2}$ lies between 50 and 100 . The similarity factor and a similarity testing have been recommended for dissolution profile comparison in the Food and Drug Administration (FDA)'s Guidance for Industry. The $\mathrm{f}_{2}$ is calculated using the formula given below:

$$
\left.\mathrm{f}_{2}=50 \log \left\{1+1 / \mathrm{n} \sum_{\mathrm{t}}^{\mathrm{n}=1}(\mathrm{Rt}-\mathrm{Tt}) 2\right]-0.5^{*} 100\right\},
$$

where $R_{t}$ is the percentage of reference product dissolved at a specified time, $T_{t}$ is the percentage of test product dissolved at a specified time, and $\mathrm{n}$ is the number of sampling points.

\section{Pharmacokinetic study ${ }^{[14,15]}$}

To study the release kinetics, the data obtained from in vitro drug release studies were plotted in various kinetic models as follows:

1. Zero order: Cumulative $\%$ of drug released versus time $\left(\mathrm{Q}_{\mathrm{t}}=\mathrm{Q}_{0}-\mathrm{K}_{0} \mathrm{t}\right)$;

2. First order: $\log$ cumulative $\%$ of drug remaining versus time $\left(\ln \mathrm{Q}=\ln \mathrm{Q}_{0}-\mathrm{K}_{1} \mathrm{t}\right)$;

3. Higuchi: Cumulative $\%$ of drug released versus square root of time $\left(\mathrm{Q}=\mathrm{Kt}^{1 / 2}\right)$; and

4. Korsmeyer-Peppas: Log cumulative $\%$ of drug released versus log time $\left(\mathrm{M}_{\mathrm{t}} / \mathrm{M}_{\alpha}=\mathrm{K} \mathrm{t}^{\mathrm{n}}\right)$,

where $Q_{i}$ and $K_{i}$ stand for the amount of drug release and kinetic release constant, respectively. $\mathrm{M}_{\mathrm{t}} / \mathrm{M}_{\alpha}$ indicates the fractional drug release and " $n$ " is the diffusional exponent which gives the mechanism of drug release. When $n<0.5$, the drug diffuses through the polymeric matrix by a Fickian (case I) diffusion mechanism. For $0.5<n<1$, an anomalous (non-Fickian) mechanism occurs; $n=1$ indicates a zero-order (case II) and $n>1$ indicates non-Fickian super case II release mechanism.

The plots were drawn using Microsoft excel 2007 and the regression equations were obtained for each plot. The linearity of the plots was obtained from the value of regression coefficient $(R)$. The model with the highest linearity ( $R$ value approaching unity) was chosen as the best fit kinetic model.

\section{Accelerated stability studies ${ }^{[16]}$}

Short-term accelerated stability studies were performed on the optimized tablet formulations of blister packed cephalexin extended release tablets. The tablets were subjected to stability studies at $40^{\circ} \mathrm{C} / 75 \%$ relative humidity $(\mathrm{RH})$ in a stability chamber (Servewell Instrument Pvt. Ltd., Bengaluru, India) for a period of 1 month. Initial evaluation 
of the tablets was done, and at the end of first month the tablets were again analyzed for their physical appearance, water content and in vitro drug release profile.

\section{RESULTS AND DISCUSSION}

The bulk density of granules was found to be between $0.54 \pm 0.32$ and $0.58 \pm 0.41 \mathrm{~g} / \mathrm{cm}^{3}$. This indicates good packing capacity of granules. Carr's index was found to be between $16.14 \pm 0.19$ and $19.97 \pm 0.54$, showing good flow characteristics. Hausner's ratio ranged from $1.19 \pm 0.38$ to $1.24 \pm 0.33$, which indicates good flowability. The angle of repose of all the formulations was within the range of $32^{\circ} 21^{\prime} \pm 0.57$ to $35^{\circ} 26^{\prime} \pm 0.25$, i.e. the granules of cephalexin have fair flow properties.

The thickness ranged from $5.43 \pm 0.08 \mathrm{~mm}$ to $5.57 \pm 0.07 \mathrm{~mm}$, and the hardness ranged from $10.26 \pm 1.11 \mathrm{~kg} / \mathrm{cm}^{2}$ to $12.59 \pm 2.20 \mathrm{~kg} / \mathrm{cm}^{2}$. The friability ranged from $0.02 \pm 0.67$ to $0.06 \pm 0.18$. The values of percentage weight variation ranged from $1.12 \pm 3.19$ to $2.74 \pm 2.79$. Drug content ranged from $98.48 \pm 0.12 \% \mathrm{w} / \mathrm{w}$ to $94.89 \pm 0.13 \% \mathrm{w} / \mathrm{w}$, indicating good content uniformity among the prepared formulations.

\section{Multiple regression analysis}

Backward regression analysis technique was used to generate the best fit models for the analyzed responses. The equations were obtained both for coded and actual values of factors. The final equation of reduced model contains only the significant factor terms corresponding to the response analyzed.

Reduced model equation for responses in terms of actual factors:

1. Release at $1^{\mathrm{st}} \mathrm{h}\left(\mathrm{Y}_{1}\right)=24.49-0.18$ HPMC K15M +1.08 HPMC 15cps - 0.009 HPMC 15cps ${ }^{2}$

2. Release at $2^{\text {nd }} \mathrm{h}\left(\mathrm{Y}_{2}\right)=46.35-0.35 \mathrm{HPMC}$ $\mathrm{K} 15 \mathrm{M}+1.047 \mathrm{HPMC} 15 \mathrm{cps}^{2}-0.008$ HPMC $15 \mathrm{cps}^{2}$

3. Release at $4^{\text {th }} \mathrm{h}\left(\mathrm{Y}_{3}\right)=102.2-0.5665$ HPMC K15M

Reduced model equation for responses in terms of coded factors:

1. Release at $1^{\text {st }} h\left(Y_{1}\right)=41.93-2.05 X_{1}-7.05 X_{2}-1.89$ $\mathrm{X}_{2}^{2}$

2. Release at $2^{\text {nd }} h\left(\mathrm{Y}_{2}\right)=61.10-4.06 \mathrm{X}_{1}-4.85 \mathrm{X}_{2}-1.67$ $\mathrm{X}_{2}^{2}$

3. Release at $4^{\text {th }} \mathrm{h}\left(\mathrm{Y}_{3}\right)=75.94-6.57 \mathrm{X}_{1}$

The inferences from reduced model analysis are: The release at $1^{\text {st }}$ and $2^{\text {nd }} \mathrm{h}$ is influenced by both the polymers. The reduced model equation in actual factors indicates that
HPMC K15M decreases the drug release from the tablet during $1^{\text {st }}, 2^{\text {nd }}$ and $4^{\text {th }} \mathrm{h}$ as the coefficients carry a negative sign. It also indicates that the HPMC 15cps increases the drug release from the tablet during $1^{\text {st }}$ and $2^{\text {nd }} \mathrm{h}$ as the coefficients carry a positive sign and the polymer has no effect at the $4^{\text {th }} \mathrm{h}$ as it is a non-significant term.

\section{ANOVA (Analysis of variance) studies}

The ANOVA of $1^{\text {st }} \mathrm{h}$ from Table 8 indicates that both HPMC K15M and HPMC $15 \mathrm{cps}$ are significant terms as the $F$ values are above the critical $F$ values, thus making the $P$ values less than 0.05 (threshold level). Thus, the null hypothesis $\mathrm{H}_{0}$ is rejected and the alternate hypothesis that the two polymers used significantly influence the rate of drug release from the cephalexin matrix tablets is found to be true.

The ANOVA of $2^{\text {nd }} \mathrm{h}$ from Table 9 shows that both HPMC K15M and HPMC 15cps are significant terms, indicating that both the polymers influence the rate of drug release at the $2^{\text {nd }} \mathrm{h}$ from the cephalexin matrix tablets and the alternate hypothesis holds good in this case.

The ANOVA of $4^{\text {th }} \mathrm{h}$ from Table 10 indicates that the only term significant is HPMC K15M, and HPMC 15cps was found to have no influence in the $4^{\text {th }} \mathrm{h}$ release from cephalexin matrix tablets. The polymer HPMC 15cps with a low viscosity is found to have rate-controlling effect only in the initial hours and HPMC K15M with a higher viscosity grade has rate-controlling effects even in the $4^{\text {th }} \mathrm{h}$.

The 3D response surface plots give a representation of

Table 8: Analysis of variance for $1^{\text {st }} \mathbf{h}$

\begin{tabular}{lccccc}
\hline Source & Sum of squares & DF & Mean square & F ratio & $P$ value \\
\hline A: K15M & 25.2971 & 1 & 25.2971 & 55.09 & $0.0051^{*}$ \\
B: 15 CPS & 298.638 & 1 & 298.638 & 650.40 & $0.0001^{*}$ \\
AA & 0.309422 & 1 & 0.309422 & 0.67 & 0.4719 \\
AB & 1.24323 & 1 & 1.24323 & 2.71 & 0.1984 \\
BB & 7.13161 & 1 & 7.13161 & 15.53 & $0.0291^{*}$ \\
Total error & 1.37749 & 3 & 0.459162 & & \\
Total (corr.) & 333.997 & 8 & & & \\
\hline
\end{tabular}

*Significant values. "DF" stands for degree of freedom

Table 9: Analysis of variance for $2^{\text {nd }} h$

\begin{tabular}{lccccc}
\hline Source & Sum of squares & DF & Mean square & F ratio & $\boldsymbol{P}$ value \\
\hline A: K15M & 99.0641 & 1 & 99.0641 & 205.77 & $0.0007^{*}$ \\
B: $15 \mathrm{CPS}$ & 141.329 & 1 & 141.329 & 293.57 & $0.0004^{*}$ \\
AA & 0.605 & 1 & 0.605 & 1.26 & 0.3439 \\
AB & 0.0676 & 1 & 0.0676 & 0.14 & 0.7328 \\
BB & 5.5778 & 1 & 5.5778 & 11.59 & $0.0423^{*}$ \\
Total error & 1.44427 & 3 & 0.481422 & & \\
Total (corr.) & 248.088 & 8 & & & \\
\hline
\end{tabular}

*Significant values. "DF" stands for degree of freedom 
the variations in each response when the two factors are simultaneously changed from lower level to higher level. They also give a three-dimensional curvature of the change in response at different factor levels and also give the variation in design points from the predicted response value. The response plots are shown in Figures 3-5.

\section{Pharmacokinetic report}

The kinetic summary from Table 11 reveals that cephalexin extended release tablets follow zero-order kinetics as the regression coefficients approach unity, indicating that the drug release is independent of drug concentration. The $n$ values from Korsemeyer-Peppas model show that the drug release pattern follows mainly Fickian diffusion mechanism, but erosion too plays a significant role as the formulations F3, F6, F9 show $\mathrm{n}$ values above 0.5 . The Higuchi plots also show good linearity, indicating that the drug release is proportional to the square root of time and the drug release is at a slower rate as the distance of diffusion increases.

\section{Comparison of dissolution profiles}

The similarity factor $\left(f_{2}\right)$ shown in Table 12 indicates that F3 gave the most similar dissolution profile to that of the marketed product. Thus, F3 was determined as the optimized product and is preferred for scale-up batches. The drug release pattern of optimized product F3 and theoretical release pattern were compared to determine the similarity and is shown in Figure 6. The graph shows good

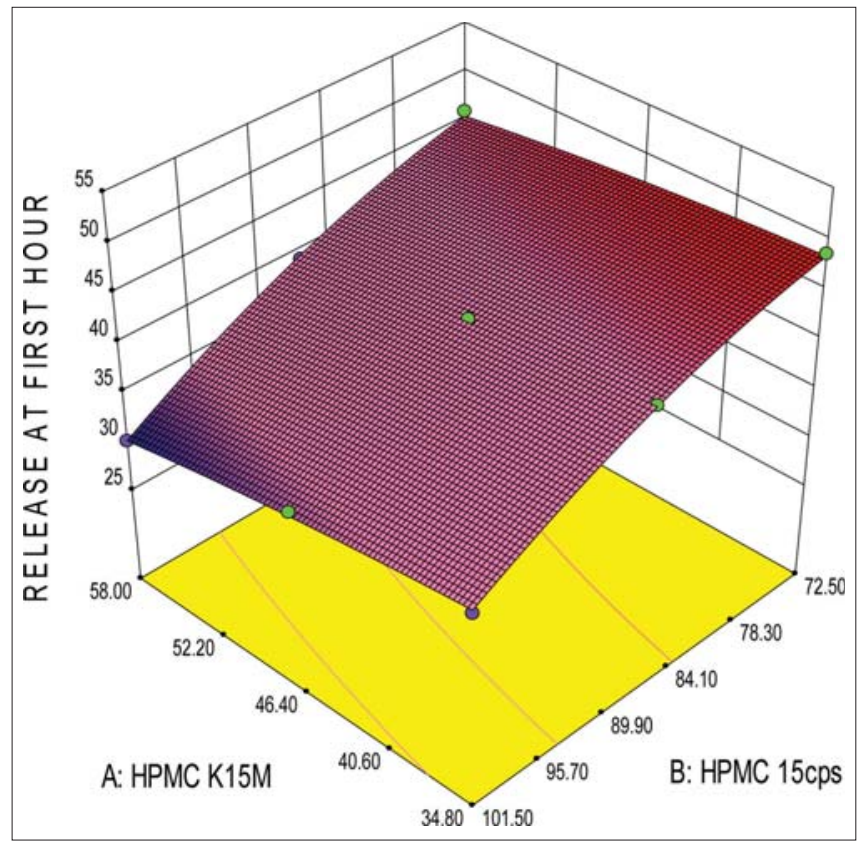

Figure 3: 3D plot for percentage drug release at the $1^{\text {st }} \mathrm{h}$ correlation between the dissolution profiles of marketed product $\mathrm{F} 3$ and the theoretical release pattern.

\section{Accelerated stability study report}

The accelerated stability study report shown in Table 13 reveals that the formulation has not undergone any physical or chemical degradation during the period. There are no significant differences in the in vitro drug release and the drug content of the optimized formulation.

Table 10: Analysis of variance for $4^{\text {th }} \mathrm{h}$

\begin{tabular}{lccccc}
\hline Source & Sum of squares & DF & Mean square & F ratio & $P$ value \\
\hline A: K15M & 259.121 & 1 & 259.121 & 127.28 & $0.0015^{*}$ \\
B: 15 CPS & 6.0 & 1 & 6.0 & 2.95 & 0.1845 \\
AA & 2.42734 & 1 & 2.42734 & 1.19 & 0.3547 \\
AB & 0.9604 & 1 & 0.9604 & 0.47 & 0.5415 \\
BB & 0.435556 & 1 & 0.435556 & 0.21 & 0.6752 \\
Total error & 6.10751 & 3 & 2.03584 & & \\
Total (corr.) & 275.052 & 8 & & & \\
\hline
\end{tabular}

*Significant values "DF" stands for degree of freedom

Table 11: Kinetics modeling summary

\begin{tabular}{|c|c|c|c|c|c|c|c|c|}
\hline \multirow[t]{3}{*}{ Code } & \multicolumn{8}{|c|}{ Kinetic model } \\
\hline & \multicolumn{2}{|c|}{ Zero order } & \multicolumn{2}{|c|}{ First order } & \multicolumn{2}{|c|}{ Korsemeyer } & \multicolumn{2}{|c|}{ Higuchi } \\
\hline & $\mathbf{R}^{2}$ & $\mathbf{K}_{0}$ & $\mathbf{R}^{2}$ & $\mathbf{K}_{1}$ & $\mathbf{R}^{2}$ & n & $\mathbf{R}^{2}$ & $\mathbf{K}_{\mathrm{H}}$ \\
\hline $\mathrm{F} 1$ & 0.964 & 9.950 & 0.844 & 0.679 & 0.967 & 0.45 & 0.960 & 34.48 \\
\hline F2 & 0.970 & 15.71 & 0.876 & 0.439 & 0.963 & 0.38 & 0.958 & 31.58 \\
\hline F3 & 0.997 & 21.31 & 0.924 & 0.483 & 0.994 & 0.62 & 0.993 & 43.00 \\
\hline F4 & 0.976 & 10.45 & 0.877 & 0.635 & 0.986 & 0.45 & 0.984 & 36.48 \\
\hline F5 & 0.969 & 9.288 & 0.894 & 0.513 & 0.979 & 0.38 & 0.976 & 32.37 \\
\hline F6 & 0.997 & 20.90 & 0.889 & 0.612 & 0.987 & 0.57 & 0.988 & 42.09 \\
\hline F7 & 0.994 & 17.75 & 0.95 & 0.573 & 0.989 & 0.43 & 0.989 & 35.80 \\
\hline F8 & 0.993 & 16.52 & 0.924 & 0.67 & 0.988 & 0.38 & 0.985 & 33.27 \\
\hline F9 & 0.993 & 21.27 & 0.995 & 0.469 & 0.985 & 0.57 & 0.990 & 42.95 \\
\hline
\end{tabular}

$\mathrm{R}^{2}=$ regression coefficient, $\mathrm{K}_{0}=$ zero-order release rate constant, $\mathrm{K}_{1}=$ first-order release rate constant, $\mathrm{n}=$ diffusional exponent, $\mathrm{K}_{\mathrm{H}}=$ Higuchi rate constant

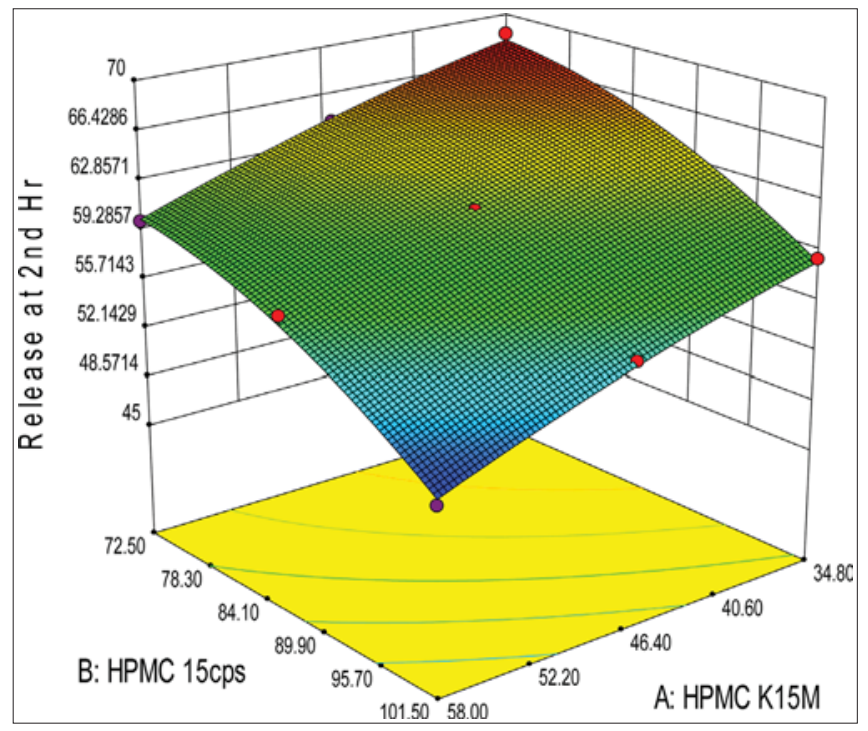

Figure 4: 3D plot for percentage drug release at the $2^{\text {nd }} \mathrm{h}$ 


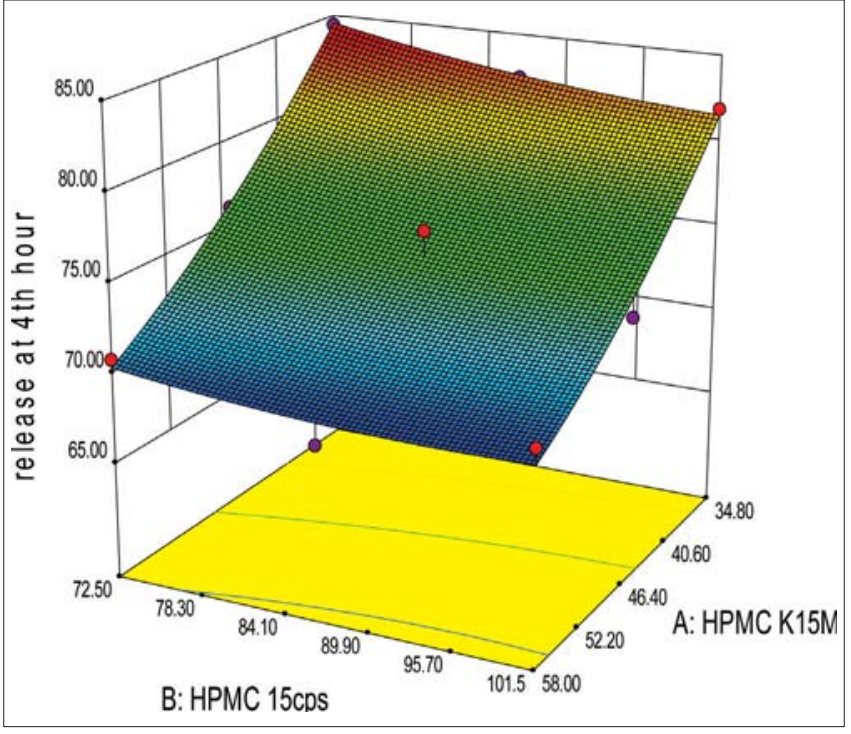

Figure 5: 3D plot for percentage drug release at $4^{\text {th }} \mathrm{h}$

Table 12: Similarity factor of formulations F1-F9

\begin{tabular}{lc}
\hline Code & Similarity factor $\left(\mathbf{f}_{2}\right)$ \\
\hline F1 & 61.13 \\
F2 & 52.72 \\
F3 & 84.78 \\
F4 & 54.66 \\
F5 & 49.05 \\
F6 & 78.53 \\
F7 & 48.80 \\
F8 & 42.97 \\
F9 & 59.19 \\
\hline
\end{tabular}

Period: 1 month. Study conditions: $40^{\circ} \mathrm{C} / 75 \% \mathrm{RH}$

Table 13: Accelerated stability studies report of cephalexin ER 375

\begin{tabular}{lcccccc}
\hline Period & \multicolumn{4}{c}{ Dissolution (\%) } & Assay (\%) & Appearance \\
\cline { 2 - 5 } & $\mathbf{1}^{\text {st }} \mathbf{h}$ & $\mathbf{2}^{\text {nd }} \mathbf{h}$ & $\mathbf{4}^{\text {th }} \mathbf{h}$ & $\mathbf{6}^{\text {th }} \mathbf{h}$ & & \\
\hline Intial & 30.18 & 49.74 & 70.24 & 94.38 & 96.12 & Off white color \\
Final & 32.54 & 53.46 & 71.69 & 96.51 & 95.47 & Off white color \\
\hline
\end{tabular}

\section{CONCLUSIONS}

The major conclusions from the study are:

1. Improvement in the efficacy of cephalexin oral therapy was achieved by formulation of cephalexin extended release matrix tablets, as the frequency of dosing was decreased, thus improving patient compliance.

2. The sawtooth kinetics of conventional therapy was completely avoided by the development of new formulation.

3. The in vitro drug release profile of the newly developed tablets also shows good similarity with that of the innnovator product and ideal controlled release pattern.

4. There were no formulation problems associated with the optimized batch of cephalexin matrix tablets.

5. The tablet also passed the short-term accelerated

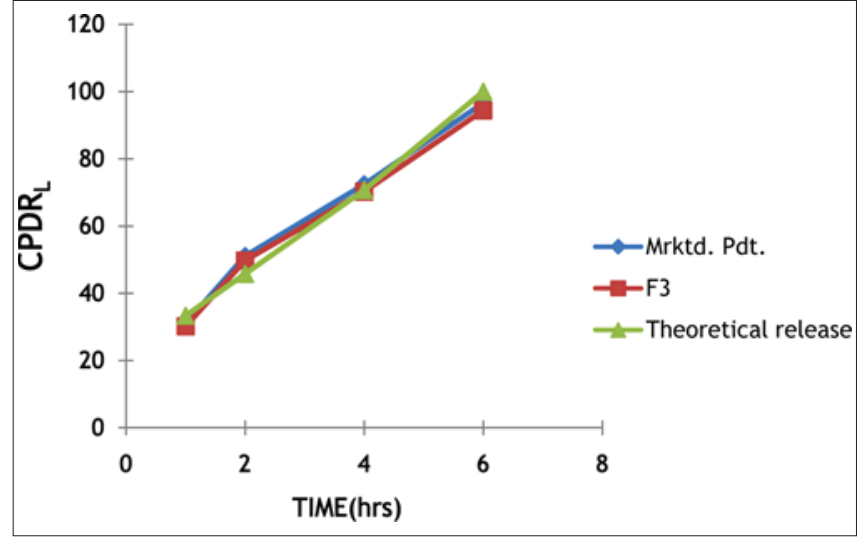

Figure 6: Comparative dissolution profiles of marketed product, F3 and theoretical release profile

stability studies, indicating the physical and chemical stability of the product.

\section{Future prospects of the study}

The marketing of the product is possible only after bioequivalence studies with innovator's product. Particle size analysis of cephalexin monohydrate and pilot-scale studies of the formulation also need to be performed. Long-term stability studies as per ICH guidelines are also proposed.

\section{REFERENCES}

1. Pogula M, Nazeer S. Extended release formulation. Int J Pharm Tech 2010;2:625-84.

2. Fyhr P,Downie K. Extended release drug delivery technology. Innov Pharm Tech 2003:80-6. Available from: http://www.iptonline.com.[cited on 2010 May 5].

3. Sweetman SC. Martindale: The Complete Drug Reference. $36^{\text {th }}$ ed. Vol. 1. London. Chicago: Pharmaceutical Press; c2009. p. 218-9.

4. Healthline: Connect to better health. San Fransisco. New York: Healthline Networks Inc.; 1999. Available from: http://www.healthline.com/ ahfscontent/cephalexin. [cited 2011 Jan 14].

5. RxList: The Internet Drug Index. California. RxList Inc. 1995. Available from: http://www.rxlist.com/keflex-drug.htm. [cited 2011 Jan 14].

6. Shin SC, Cho SJ. Kinetics of Cephalexin Release from Eudragit-Hydroxypropyl cellulose Membranes. Drug Dev Ind Pharm 1996;22:299-305..

7. Howard SA. Solids: Flow properties. In: Swarbrick J, editor. Encyclopedia of pharmaceutical technology. New York: Informa healthcare USA, Inc.; 2007. p.3281-5.

8. Shangraw RS. Compresssed tablets by direct compression. In: Lieberman HA, Lachman L, Schwartcz JB, editors. Theory and practice of industrial pharmacy. $2^{\text {nd }}$ ed. Vol.1. New York: Marcel Dekker, Inc.; c1989. p.198-203.

9. Indian pharmacopoeia 2007. Vol.1. Ghaziabad, India: Indian Pharmacopoeia Commission; c2007. p.182-3.

10. USP 30 NF 25 2007. Rockville, MD. USA: United States Pharmacopoeial Convention Inc.; 2007. p.1689.

11. Martinez Pacheco R, Vila Jato JL, Souto C, Ramos T. Controlled release of cephalexin from double-layer tablets containing small proportions of acrylic resins. Int J Pharm 1986;32:99-102.

12. Mukerjee R, Wu CFJ. A theory of factorial designs. New York: Springer Science Business Media, Inc.; c2006. p.85.

13. Shinde AJ, Patil MS, More HN. Formulation and evaluation of an oral floating tablet of cephalexin. Indian J Pharm Educ Res 2010;44:1-10.

14. Costa P, Lobo JM. Modeling and comparison of dissolution profiles. Eur 
J Pharm 2001;13:123-33.

15. Grassi M, Grassi M. Mathematical modelling and controlled drug delivery: Matrix systems. Curr Drug Deliv 2005;2:97-116.

16. Yoshioka S, Stella VJ. Stability of drugs and dosage forms. New York: Kluwer Academic Publishers; c2002. p. 205-13.
How to cite this article: Jishnu V, Prabhakaran R, Gilhotra RM. Formulation and evaluation of cephalexin extended release matrix tablets using $3^{2}$ factorial design. J Young Pharmacists 2011;3:259-66.

Source of Support: Nil, Conflict of Interest: None declared.

\section{Author Help: Online submission of the manuscripts}

Articles can be submitted online from http://www.journalonweb.com. For online submission, the articles should be prepared in two files (first page file and article file). Images should be submitted separately.

\section{1) First Page File:}

Prepare the title page, covering letter, acknowledgement etc. using a word processor program. All information related to your identity should be included here. Use text/rtf/doc/pdf files. Do not zip the files.

\section{2) Article File:}

The main text of the article, beginning with the Abstract to References (including tables) should be in this file. Do not include any information (such as acknowledgement, your names in page headers etc.) in this file. Use text/rtf/doc/pdf files. Do not zip the files. Limit the file size to $1024 \mathrm{~kb}$. Do not incorporate images in the file. If file size is large, graphs can be submitted separately as images, without their being incorporated in the article file. This will reduce the size of the file.

3) Images:

Submit good quality color images. Each image should be less than $\mathbf{4 0 9 6} \mathbf{~ k b ~ ( 4 ~ M B ) ~ i n ~ s i z e . ~ T h e ~ s i z e ~ o f ~ t h e ~ i m a g e ~ c a n ~ b e ~ r e d u c e d ~ b y ~ d e c r e a s - ~}$ ing the actual height and width of the images (keep up to about 6 inches and up to about $1800 \times 1200$ pixels). JPEG is the most suitable file format. The image quality should be good enough to judge the scientific value of the image. For the purpose of printing, always retain a good quality, high resolution image. This high resolution image should be sent to the editorial office at the time of sending a revised article.

4) Legends:

Legends for the figures/images should be included at the end of the article file. 